\title{
THE CULTURAL COMPETENCY SCALE FOR CLINICAL PEDIATRIC NURSE (CCS-CPN) IN INDONESIA: SCALE DEVELOPMENT AND PSYCHOMETRIC EVALUATION
}

\author{
Dewi Elizadiani Suza
}

Pediatric Department Faculty of Nursing, Universitas Sumatera Utara, Indonesia

\begin{abstract}
Nurses play an important role to apply practice in cultural competence in hospitals. To perform this role nurses need to provide information on the conceptual aspects of cultural competence by using instruments and assessing cultural competence in a clinical setting. This study aimed to develop the cultural competency for clinical pediatric nurse (CCS-CPN), and do psychometric evaluation of the validity and reliability of CCS-CPN. An inductive method was used to develop an instrument to measure nurse perceptions of CCS-CPN. The scale validation was conducted among 450 general hospital nurses recruited using purposive sampling method from twenty general hospitals in Indonesia. DeVellis' eight-step plan was used to establish guidelines for development the CCS-CPN. The data was examined using exploratory factor analysis (EFA) which is a method to identify the internal dimensions of the CCS-CPN. Using an EFA, 30-items with a six-factor structure were retained to form the CCSCPN. These factors describe: culture awareness of pediatric nurse; culture knowledge of pediatric nurse; culture skill of pediatric nurse; culture encounter of pediatric nurse; culture desire of pediatric nurse; and culture sensitivity of pediatric nurse. The 30-item CCS-CPN yielded an overall Cronbach's alpha-coefficients .85. The Cronbach's alpha-coefficients for the CCS-CPN subscales were .81, .73, $.81, .75, .78$ and .87 , respectively. The 30 -item CCS-CPN version of Indonesia consists of six-factors were acceptable and significant. Unfortunately, factor 4 obtained an item that does not represent the dimensions of the culture encounter of pediatric nurses. Therefore, further research is needed by using different method of Delphi method.
\end{abstract}

Key words: Culture competency, pediatric nurse, children

\begin{abstract}
ABSTRAK
Perawat memainkan peran penting untuk menerapkan praktek dalam kompetensi budaya di rumah sakit. Untuk melakukan peran ini perawat perlu memberikan informasi tentang aspek konseptual kompetensi budaya dengan menggunakan instrumen dan menilai kompetensi budaya dalam pengaturan klinis. Penelitian ini bertujuan untuk mengembangkan kompetensi budaya untuk perawat klinis (CCS-CPN), dan melakukan evaluasi psikometri terhadap validitas dan reliabilitas CCS-CPN. Metode: Metode induktif digunakan untuk mengembangkan instrumen guna mengukur persepsi perawat klinis (CCS-CPN). Validasi skala dilakukan dengan cara purposive sampling dari 450 perawat di rumah sakit umum yang direkrut dari dua puluh rumah sakit umum di Indonesia. Delapan langkah DeVellis digunakan untuk menetapkan pedoman untuk pengembangan CCS-CPN. Data diperiksa menggunakan eksploratori faktor analisis (EFA) adalah metode untuk mengidentifikasi dimensi internal CCS-CPN. Menggunakan EFA, 30-item dengan struktur enam faktor dipertahankan untuk membentuk CCS-CPN. Faktor-faktor ini menggambarkan: kesadaran budaya perawat anak; pengetahuan budaya perawat anak; keterampilan budaya perawat anak; pertemuan budaya perawat anak; keinginan budaya perawat anak; dan sensitivitas budaya perawat anak. Tiga puluh item CCS-CPN menghasilkan keseluruhan alpha-koefisien Cronbach .85. Koefisien alpha Cronbach untuk subskala CCS-CPN berturut-turut adalah $0,81, .73, .81, .75, .78$ dan .87. Tiga puluh item CCS-CPN versi Indonesia terdiri dari enam-faktor yang dapat diterima dan signifikan. Sayangnya, faktor 4 memperoleh item yang tidak mewakili dimensi pertemuan budaya perawat anak. Oleh karena itu, penelitian lebih lanjut diperlukan dengan menggunakan metode Delphi metode yang berbeda.
\end{abstract}

Kata kunci: Kompetensi budaya, perawat anak, anak-anak 


\section{BACKGROUND}

Indonesian culture is influenced by several factors, namely customs and influenced by foreign cultures. Besides that, Indonesia was also influenced by ancient trade, including eastern culture, south Asia and the Middle East which had an impact on cultural practices which were strongly influenced by social status, ethnicity, race, religion, and belief. Therefore a complex mix of cultures shows different cultural results from the original (Wikipedia, 2018). Therefore, culture not only affects health practices, but also how health care providers and patients perceive the disease (Murphy, 2011). In practicing the profession, health care team in Indonesia must have the ability to find diversity in the relationship between nurse-patient interactions. To be able to build effective relationships with patients or families, health professionals must have skills related to cultural competence. Cultural competence helps health care team in understanding the cultural background of patients or families in order to provide high quality of health services. Cultural competence is one of several aspects of the professionalism of health care team. In clinical settings, cultural competence must focus on attitudes and behavioral changes towards diversity. Nurses play an important role in applying practices in cultural competence in hospitals. To perform this role nurses need to provide information about the conceptual aspects of cultural competence by using instruments and assessing cultural competencies in clinical settings.

Cultural competence is important in healthcare because it is one way to cover the gap from unequal treatment with patients. The National Institutes of Health (NIH) identified cultural competence as an important factor in reducing healthcare disparities and increasing access to high quality healthcare for patients from different cultural, ethnic, and religious backgrounds (The National Institutes of Health, 2017). The lack of recognition of the importance of cultural competence in nursing care means ignoring the important role of nurses in promoting patient wellbeing and maintaining a holistic approach to health (Lin, Mastel-Smith, Alfred, \& Lin, 2015).

Failure to be culturally competent can lead to patient dissatisfaction. For example, The Asian-American group feels that healthcare not understand the cultural background and values they hold so they experience the dissatisfaction while being treated in hospital. De Beer and Chipps (2014) stated that healthcare that do not have skills in cultural competence may have a negative impact on patients, such as the risk of delay in treatment, improper diagnosis, non-compliance with health care regimens, and even death of patients. There is little literature available to identify and explain instruments that measure cultural competence in nursing (Loftin, Hartin, Branson, \& Reyes, 2013). Cultural competencies include gender, sexual orientation, socioeconomic status, faith, profession, taste, disability, age, and race, and ethnicity. According to CampinhaBacote (2002), cultural competence is a long-term process where nurses must continue to learn in improving the ability to work effectively in the context of the patient's culture. This process includes cultural desires, cultural awareness, cultural knowledge, cultural skills, and cultural meetings. For someone who is not a member of a particular group, cultural diversity is increasingly diverse because of the diversity of ethnic, linguistic, religious and religious backgrounds that have implications in the field of nursing. Although, health arrangements are representative of several different cultures; nurses have limitations in the practice of cultural competence. Incorporating cultural competencies in nursing education curricula, organizational policies, and research will help prepare nurses to work in cultural competency practices (Magdalena, 2009).

Loftin et al. (2013) identified that tools for assessing cultural competence in nursing and nursing students are selfmanaged and based on individual perceptions. Such a tool is usually used to assess the effectiveness of educational programs designed in enhancing cultural competence. The tool reviewed measures self-perceptions of nurses or self-reported 
level of cultural competence but does not measure objectively for culturally competent nursing care from a patient's perspective that may be a problem (Loftin et al., 2013). Therefore, an assessment framework for cultural competence should be performed by nurses with assessments that emphasize inclusion care with a holistic caring approach that includes the physical, psychological, social, and cultural needs of the patient. Shen (2015) reports that there are several models of cultural competence and cultural competence assessment tools developed, but most of them were not empirically tested and very few have developed model-based on tools. The limitations of the models and tools developed affect the cultural competence of health service.

Lack of research on cultural nursing and knowledge of cultural differences makes nurses or other health care providers difficult to provide quality services and cost effective treatments. Although there are similarities between people or patients in the world, there are also differences that arise from cultural, religious, family background and individual or group experiences which affecting care. This difference not only affects the patient's values, beliefs and behaviors, but also supports the idea of health care and affects patient expectations.

American Nursing Association stated that nurses must understand how different are within culturally diverse groups (Olin, 2011). Therefore nurses must understand how to understand their culture, how they determine the health and severity of the disease, how they believe in the cause of the illness they are suffering, and how they care for family members with the illness. Lack of awareness and unsuccessful nurses in providing culturally competent nursing care can increase the stress or pressure experienced by patients or families and can lead to less optimal nursing care. Research conducted by Hardy et al. (2011) found that few issues related to the cultural competence including lack of familiarity between families and nurses, difficulties in communicating, religious diversity, difficulty in obtaining information, distrust of health services, and the discomfort of discrimination. The difficulty often experienced by nurses in applying cultural competence is stereotypes to patients. Nurses often have prejudice to patients or their family for a particular culture or ethnic group based on characteristics such as appearance, response, ethnicity, country of origin, or custom of a particular religious group.

Berlin, Nilsson, and Törnkvist (2010) conducted a study of 51 child nurses working in hospitals, which divided into 2 groups: 1) 24 child nurses in intervention group conducted cultural competence training and 2) 27 child nurses in the control group did not receive training. The results showed significant improvements in the areas of cultural knowledge, cultural skills, and cultural gatherings among child care nurses who get training. There are $92 \%$ of child nurses from the intervention group showed an increase desire to learn more about culturally competent health services. Davies, Larson, Contro, and Cabrera (2011) conducted a study of 13 MexicanAmerican Families whose children were admitted in hospital for diseases that restricted family activity in hospitals. Families get different treatment in places where their child is being treated. NonHispanic white patients feel the difference in health services for their children with special needs compared to other ethnic groups. Delayed care is reported more frequently by Hispanic white patients, followed by other Hispanic/Hispanic blacks (Kerfeld, Hoffman, Ciol, \& Kartin, 2011). Research conducted by Tavallali, Kabir, and Jirwe (2014) found that communication between patients and minority nurses is the most important and key indicator of successful nursing care quality. All parents involved in the study expressed the importance of ethnic minority nurses with skills. They dissatisfied with nursing care provided by minority nurses.

Barriers to cultural sensitivity in the nursing profession may include stereotypes, discrimination, racism, and prejudice. There are situations where individual can describe the lack of 
sensitivity without realizing it or intending to offend others. Simple steps to show respect such as calling patients using their last names or asking how they want to be handled. In addition, there is limited research to inform care providers in children, especially doctors and nurses about their progress in providing culture competent care for their patients and parents and what problems arise as they care for different populations. Although, there are a large number of literatures investigating why it is important to provide culture competent care for patient populations, a guide to prepare culturalbased care competencies in quickly changing demographic culture worldwide is needed.

Furthermore, Cai, Kunaviktikul, Klunklin, Sripusanapan, and Avant (2017) in their study stated that there is no framework or instrument for cultural competence for nurses to guide nursing practice in China where the population has cultural diversity and the characteristics of the health care system in China differ from western countries. In Indonesia there is little or no knowledge of the patient's cultural background, socio-economic, ethnic, linguistic, and religious especially for pediatric patients. Cultural competence among nurses has received little attention in Indonesia; and the lack of formal education and training for nurses may contribute to the lack of culturally competent care. Therefore, psychometric development and evaluation of Cultural Competency Scale for Clinical Pediatric Nurse (CCS-CPN) in Indonesia is urgently needed. This scale can serve as a guide for child nurses to provide cultural competence and identify strengths or weaknesses in the delivery of nursing care.

\section{METHODS}

Inductive design was used to develop Indonesian cultural competency for clinical pediatric nurse instrument and evaluate its psychometric property. Objectives of this study were: 1) to develop the cultural competency for clinical pediatric nurse (CCS-CPN), and 2) to perform psychometric evaluation of the validity and reliability of CCS-CPN. In this study, the setting was in general hospitals, Indonesia. Based on DeVellis, (2012), scale development procedures involved the following eight steps.

Step 1: Review Literature: based on the literature review regarding cultural competency in nursing, in-depth interviewed $(n=15)$ and the focus group discussion $(n=30)$, six-dimensions and 75 items of the Cultural Competency Scale for Clinical Pediatric Nurse (CCS-CPN) in Indonesia were identified. It consisted of 1) culture awareness of pediatric nurse (18 items), 2) culture knowledge of pediatric nurse (17 items), 3) culture skill of pediatric nurse (16 items), 4) culture encounter of pediatric nurse (7 items), 5) culture desire of pediatric nurse ( 8 items), and 6) culture sensitivity of pediatric nurse (9 items).

Step 2: Generation of an item Pool: the six-dimensions of the CCS-CPN were performed based on data collected from literature review, focus group, and interview, then it generated into a large pool of items.

Step 3 Determination of item format: fivepoint Likert scale was used to increase response rate and response quality along with reducing respondents' frustration level.

Step 4: Determination of validity: content validity of the CCS-CPN was conducted by pediatric nurses from five hospitals. The Content Validity Index (CVI) was .86. Twelve items were modified because of lack of clarity. Thus, the CCS-CPN consisted of six-dimensions with 75 items.

Step 5: Pre-test: the Cronbach's alpha coefficients for overall scale and its six dimensions were $.86, .81, .81, .78, .78$, and .73, respectively.

Step 6: Field-test: the researcher administered the CCS-CPN, demographic data form, and Marlowe-Crowne Social Desirability Scale (MCSDS) to 450 pediatric nurses at twenty pediatric wards in Indonesia. Purposive sampling was used to recruit the respondents who met the inclusion criteria. The inclusion criteria consist of: 1) pediatric nurses who have provided nursing care to children and 2) pediatric nurses were having a bachelor 
degree and the work experience of working in pediatric wards.

Data collection: after an approval from the Ethics Committee at Faculty of Nursing, University of Sumatera Utara, Indonesia and the directors of nursing from twenty general hospitals in Indonesia, the survey packages were distributed to respondent through the head nurse of the pediatric ward in each general hospital from June to October, 2017. Each survey package included a cover letter, CCS-CPN, demographic data form, MCSDS, and informed consent form. Respodent were asked to complete the questionnaires and return it to the researcher.

Step 7: Evaluation of items: at this step, the performance of the individual items was evaluated by processing rotation according to EFA principle.

Step 8: Determination of reliability: this step consisted of 1) internal consistency, 2) test-retest, and 3) contrasted group approach.

\section{RESULTS}

After testing the assumptions for EFA, 450 participants were retained for further analysis

Table 1. Demographic Data of Pediatric Nurses ( $\mathrm{N}=450)$

\begin{tabular}{|c|c|c|}
\hline Items & Frequency & Percent \\
\hline \multicolumn{3}{|l|}{ Gender } \\
\hline Male & 63 & 14.00 \\
\hline Female & 387 & 86.00 \\
\hline \multicolumn{3}{|l|}{ Age (years) } \\
\hline$<30$ years old & 91 & 20.00 \\
\hline $30-40$ years old & 319 & 71.00 \\
\hline$>40$ years old & 40 & 9.00 \\
\hline \multicolumn{3}{|l|}{ Religion } \\
\hline Muslim & 246 & 55.00 \\
\hline Christian & 198 & 44.00 \\
\hline $\begin{array}{l}\text { Catholic } \\
\text { Marital Status }\end{array}$ & 6 & 1.00 \\
\hline Single & 166 & 37.00 \\
\hline \multicolumn{2}{|l|}{ Education } & 63.00 \\
\hline Bachelor degree & 450 & 100.00 \\
\hline $\begin{array}{l}\text { Work experience } \\
\text { in pediatric } \\
\text { nursing }\end{array}$ & & \\
\hline$<6$ years & 179 & 40.00 \\
\hline 6 years & 84 & 19.00 \\
\hline$>6$ years & 187 & 41.00 \\
\hline
\end{tabular}

\section{Construct Validity}

To test for the construct validity of the CCS-CPN, the distributions and Pearson correlation coefficients between the variables were first examined. The descriptive statistics indicated the absence of highly skewed distribution and kurtosis. The results of the correlational analysis showed that no pairs of variables were highly correlated based on Munro's criteria (Munro, 2005). The scatter plot showed strong linear relationship with positive correlation. In factor analysis, the most commonly recommended approach for outlier detection is the Mahalanobis Distance and box plots. Using a criterion of $p$-values equals to .001 with $75 \mathrm{df}$, critical $X^{2}$ equaled $118.59,40$ outliers were deleted. Therefore, 450 participants were retained.

At first, an EFA was performed with the 75 item CCS-CPN. Regretable, the model was unworthy. Thus, an itemtotal correlation was established. The results revealed that 17 items had low item-total correlations, ranging from .06 to .30. Those showed that the items might be less consistent and less reliable to reflect the construct when compared with items in the 75 item CCS-CPN. Consequently, seventeen items were eliminated from 75 item CCS-CPN. Accordingly, 58 items were used to further carry out the EFA and finally resulting in the 30 items.

The model fit interpretation

In this study, EFA was performed various times with the CCS-CPN. The final model is composed of 30 items. Before interpretation of the results, the model fit of the 30 items CCS-CPN were identified. A Kaiser-Meyer-Olkin index of the model was satisfactory (.87). Bartlett's test of sphericity was significant. The Eigen values represent 16 factors and Scree test showed 5-6 factors. The percentages of total variance explained. The variances explained for each factor were acceptable only for the model of 30 item CCS-CPN (total $43.21 \%$, each factor varied from $20.71-5.23 \%$ ). The Eigen values of the 30 item CCS-CPN ranged from 2.00 to 12.43 . 
Table 2. The Criteria of EFA for selecting the optimal number

\begin{tabular}{|c|c|c|}
\hline $\begin{array}{l}\text { Methods/The } \\
\text { criteria to be } \\
\text { retained }\end{array}$ & $\begin{array}{l}30 \text { items } \\
\text { CCS-CPN }\end{array}$ & $\begin{array}{l}\text { Normal } \\
\text { Value }\end{array}$ \\
\hline $\begin{array}{l}\text { Factor } \\
\text { method }\end{array}$ & PAF & $\begin{array}{l}\text { PAF may be } \\
\text { used because } \\
\text { of the data } \\
\text { are not } \\
\text { normally } \\
\text { distributed }\end{array}$ \\
\hline $\begin{array}{l}\text { Factor } \\
\text { method }\end{array}$ & Varimax & $\begin{array}{l}\text { Varimax } \\
\text { rotations } \\
\text { produce } \\
\text { factors that } \\
\text { are } \\
\text { uncorrelated }\end{array}$ \\
\hline $\mathrm{KMO}$ & .87 & $\geq .60$ \\
\hline $\begin{array}{l}\text { Bartlett's test } \\
\text { of sphericity }\end{array}$ & .000 & Sig.000 \\
\hline Eigen values & 1 & $\geq 1$ \\
\hline Scree test & $5-6$ & $\begin{array}{l}\text { Data points } \\
\text { above the } \\
\text { break }\end{array}$ \\
\hline $\begin{array}{l}\text { Percent of } \\
\text { total variance } \\
\text { explained }\end{array}$ & 43.21 & $40 \%$ or more \\
\hline
\end{tabular}

Factors, items, and factor loadings

Factors, items, and factor loadings were interpreted for 30 items CCS-CPN because it had a model fit. The 30 item CCS-CPN is composed of six factors. The factor loadings consist of: factor 1 culture awareness ( 5 items, varied from .46 to .84, $\mathrm{p}=.000$ ), factor 2 culture knowledge ( 6 items, varied from .45 to .76 , $\mathrm{p}=.000$ ), factor 3 culture skill (5 items, varied from .54 to $.84, \mathrm{p}=.000)$, factor 4 culture encounter ( 3 items, varied from .40 to .63, $\mathrm{p}=.000)$, factor 5 culture desire (4 items, varied from .62 to $.84, p=.000)$ and factor 6 culture sensitivity ( 7 items, varied from .52 to $.79, p=.000$ ) were acceptable and significant.

\section{Contrasted group approach result}

The results revealed that the mean scores of the 30 items Indonesian version of CCS-CPN among pediatric nurses who have work experience six years or more (group 1, $n=271$ ) were significantly higher than those of nurses (group 2, $\mathrm{n}=179$ ) have work experience less than six years $(M=4.11, S D=0.25$; $\mathrm{M}=2.94, \mathrm{SD}=0.29 ; \mathrm{t}=8.55, \mathrm{p}=.000)$.
Table 3. The mean (M), standard deviation (SD), and $t$ of the Indonesian version of CCS-CPN

\begin{tabular}{llll}
\hline Groups & \multicolumn{3}{l}{$\mathbf{3 0}$ item CCS-CPN } \\
\cline { 2 - 4 } & Mean (SD) & $\boldsymbol{t}$ & $\boldsymbol{P}$ (1-tailed) \\
\hline 1 & $4.11(0.25)$ & $8.55^{\star}$ & .000 \\
2 & $2.94(0.29)$ & & \\
\hline
\end{tabular}

\section{Reliability}

The Cronbach's alpha coefficients of total 30 items CCS-CPN were excellent (.85). Cronbach's alpha coefficients of each factor of the 30 items CCS-CPN were $.83, .73, .70, .70, .81$, and .83 , respectively. The test-retest results revealed that the mean score of the overall 75 item CCS-CPN and its factors measured at Time 1 were positively significant and high correlated with those of measured at Time 2. The means are similar and $r$ is strong and positive $(r=$ .70).

\section{Social desirability}

Social desirability test was used to examine the tendency among pediatric nurses to answer in a socially desirable way when taking some personality tests.. In this study, the Indonesian version of Marlowe-Crowne Social Desirability ScaleC (MCSDS-C) was used to establish the degree of social desirability to the respondents answer true or false to a set of socially desirable, but impossible statements. The on the whole mean scores of the 30 items of the CCS-CPN did not significant and positively correlated with that of the social desirability $(r=.06$, $p=.05$ ).

\section{DISCUSSION}

The development and components of the CCS-CPN

The criteria of CCS-CPN were developed based on the following situations, including: nurses need to recognize their own cultural values in seeking cultural competence; nurses perceived the fear of mistakes and crossing boundaries related to the cultural and religious practices of minority patients as particularly stressful (Sindayigaya, 2016). Increasing cultural and linguistic competence for child nursing is extremely important for several reasons, including: 
age restrictions; eliminate the old gaps in the health status of people of different backgrounds; improve the quality of nursing care; fulfill the legislative, regulatory and accreditation mandates; gain competitive advantage in the market; and reduce the likelihood of liability/malpractice claims.

In this case for Indonesian pediatric nurses cultural competence was new concept, and they have not grasped it yet. The majority respondents had not received education or training in caring for patients with the different ethnic. They were developed cultural competency based on self- experience and feeling. This is different from developed countries; they have a curriculum on cultural competence for nursing students and clinical nurses. Language barriers are reported as the most difficult problem in treating pediatric patients. The substantial perceived barrier is the language, which is parents not fluent in English, beside communication dynamics. These findings s congruent with Beckstrand, Rawle, Callister and Mandleco (2010) studies that identify the influence of language and cultural differences on the interaction of nurses with patients and parents.

Thus, development of components of cultural competency in clinical pediatric nurse was based on an extensive review of the literature regarding cultural competency as previously mentioned, focus group discussion, indepth interview, and expert review. This study used eight steps of DeVellis's Theory of Scale Development (DeVellis, 2012). Scale Development is a process of developing a reliable and valid measure of CCS-CPN in order to assess an attribute of interest. The CCS-CPN was developed based on the Campinha-Bacote theory cultural competence (Campinha-Bacote, 2002)

\section{Construct Validity}

Even though the 30 items CCSCPN model was acceptable, but it could not decribe the culture encounter of pediatric nurses dimension because it only 3 item loading in factor 6 . This is because most of the pediatric nurses have difficult experience to encounter the patients come from different background, culture, and language. Based on the conceptual framework Bagotte theory, this study found the different dimension of cutural competency. The researcher expected that the culture competence of clinical pediatric nurse composed six-dimension, however only five-dimension that reperentative to cultural competency in clinical pediatric nurse in Indonesian.

The number of items for each dimension should be the same so that it is expected that all items will be evenly distributed for each existing dimension when the process of loading factors employed (Bolt, 2002). Inequality of the number of items for each dimension will affect the distribution of items in each dimension. Therefore if the number of items is the same per dimension, each dimension will have the same proportion. Pediatric nurses report that it is difficult to express the insecurity and uncertainty when approaching patients or families from different cultural backgrounds from themselves.

They report that they do not always know how to approach or cope when faced with patients from different cultural backgrounds or speak different language. Thus, research in the context of cultural competence for child care is required. Barrier to perform cultural encounter included 1) communication difficulties (language differences, confidentiality, and cultural identity in communication related to gender or relating to attitudes in the families), and 2) the institutional aspects that affect the delivery of excellent care to the family are respected section of the external bad distinctions tiers, determined by shortfall of space in care areas to house all family members, restriction of resources to offer food and accommodation to all family members and restricted time of the nurses to take care of the family (Murcia \& Lopez, 2016). In addition, this study was conducted in Indonesia; thus, nurses probably perform only nursing assessment in this dimension.

The contrasted group was performed and found that the mean scores 
of the two versions of the CCS-CPN were significantly different between two nurse groups. This indicated that the construct measured by the CCS-CPN was used in evaluating construct validity. Waltz, Strickland, and Lenz (2017) stated that contrasted group approach was used to compare the two groups of different experience levels using the t-test as well as to assess the ability of the CCS-CPN to detect differences experience between the different groups. The study found some evidence for construct validity in the Indonesian version of CCS-CPN. The limitation in this study is that the response rate of respondents who are slow may reflect the length of time needed to fill the CCP-CPN instrument. In this study, the cultural competence for clinical pediatric nurse in Indonesian version found that 30 items with six-dimension consisted of 1 ) culture awareness of pediatric nurse, 2) culture knowledge of pediatric nurse, 3) culture skill of pediatric nurse, 4) culture encounter of pediatric nurse, 5) culture desire of pediatric nurse, and 6) culture sensitivity of pediatric nurse. However, in the culture encounter dimension of CCSCPN it was less representative because it consisted of only 3 from 7 items which could not measure the complete dimension of the cultural encounter aspect. This is different from the Korean version of the Cultural Competence Scale for Nurses (K-CCSN). They found that the 33-item K-CCSN comprised four subscales: cultural awareness, cultural knowledge, cultural sensitivity, and cultural skills (Chae \& Lee, 2014).

\section{CONCLUSION}

The 30-item CCS-CPN version of Indonesia which consists of six factors: 1 ) culture awareness of pediatric nurses (5 items), 2) culture knowledge of pediatric nurses (6 items), 3) culture skill of pediatric nurses (5 items), 4) culture encounter of pediatric nurses (4 items), and 6) culture sensitivity of pediatric nurses (7 items) were acceptable and significant. Unfortunately, factor 4 did not represent the dimensions of the culture encounter of pediatric nurses. Therefore, further research is needed by using different method of Delphi method. It is hoped that using Delphi method will be more applicative and more representative to represent the six factors of cultural competence for Indonesian culture. The Delphi method is designed as a group communication process which aims to achieve a convergence of opinion on a specific real world issue of cultural competency.

Providing care to the patients from different cultural background is not an easy task because the nurses felt morally uncomfortable. The cultural differences were caused by insufficient knowledge of other cultures and communication problem. Therefore cultural competency instruments must be developed to increase awareness and interest in cultural differences such as ethnicity, beliefs, and religion of patients. Pediatric nurses need to recognize and consider the backgrounds of the ethnicity, beliefs, religion, and patient characteristics, so they can provide appropriate nursing care for the patient.

\section{ACKNOWLEDGMENTS}

This study was supported by a rector of Universitas of Sumatera Utara and Research Department of Universitas of Sumatera Utara.

\section{REFERENCES}

Beckstrand, R. L., Rawle, N. L., Callister, L., \& Mandleco, B. L. (2010). Pediatric nurses' perceptions of obstacles and supportive behaviors in end-of-life care. American Journal of Critical Care, 19(6), 543-552. https://doi.org/10.4037/ajcc2009497

Berlin, A., Nilsson, G., \& Törnkvist, L. (2010). Cultural competence among Swedish child health nurses after specific training: A randomized trial. Nursing and Health Sciences., 12(3), 381-391. https://doi.org/10.1111/j.14 42-2018.2010.00542.x

Bolt, D. M. (2002). A Monte Carlo Comparison of Parametric and Nonparametric Polytomous DIF Detection Methods. Applied 
Measurement in Education, 15(2), 113-141. https://doi.org/10.1207/S15 324818AME1502_01

Cai, D., Kunaviktikul, W., Klunklin, A., Sripusanapan, A., \& Avant, P. K. (2017). Developing a cultural competence inventory for nurses in China. International Nursing Review, 64(2), 215-223,. https://doi.org/10.11 $11 /$ inr.12350

Campinha-Bacote, J. (2002). The Process of Cultural Competence in the Delivery of Healthcare Services: A Model of Care. Journal of Transcultural Nursing, 13(3), 181184. https://doi.org/10.1177/1045960 2013003003

Chae, D. H., \& Lee, C. Y. (2014). Development and psychometric evaluation of the Korean version of the cultural competence scale for clinical nurses. Asian Nursing Research, 8(4), 305-312. https://doi.org/10.1016/j.anr.2014.06. 004

Davies, B., Larson, J., Contro, N., \& Cabrera, A. P. (2011). Perceptions of Discrimination among Mexican American Families of Seriously III Children. Journal of Palliative Medicine, 14(1), 71-76. https://doi. org/10.1089/jpm.2010.0315

De Beer, J., \& Chipps, J. (2014). A survey of cultural competence of critical care nurses in KwaZulu-Natal. Southern African Journal of Critical Care, 30(2), 50-54. https://doi.org/ 10.7196/SAJCC. 188

\section{DeVellis, R. F. (2012). Scale Development: Theory and Applications 3 rd ED . Vol . 26. Applied Social Research Methods.}

Hardy, D., Chan, W., Liu, C. C., Cormier, J. N., Xia, R., Bruera, E., \& Du, X. L. (2011). Racial disparities in the use of hospice services according to geographic residence and socioeconomic status in an elderly cohort with nonsmall cell lung cancer. Cancer, 117(7), 1506-1515. https://doi.org/10.1002/cncr.25669

Kerfeld, C. I., Hoffman, J. M., Ciol, M. A., \& Kartin, D. (2011). Delayed or forgone care and dissatisfaction with care for children with special health care needs: The role of perceived cultural competency of health care providers. Maternal and Child Health Journal, 15(4), 487-496. https://doi.org/10.1007/s10995-0100598-3

Lin, C. N., Mastel-Smith, B., Alfred, D., \& Lin, Y. H. (2015). Cultural Competence and Related Factors among Taiwanese Nurses. Journal of Nursing Research, 23(4), 252261. https://doi.org/10.1097/JNR.00 00000000000097

Loftin, C., Hartin, V., Branson, M., \& Reyes, H. (2013). Measures of cultural competence in nurses: An integrative review. The Scientific World Journal. https://doi.org/10.1 $155 / 2013 / 289101$

Magdalena, V. (2009). Cultural competence and holistic practice: implications for nursing education, practice, and research. Holistic Nursing Practice, 23(3), 153-157.

Munro, B. H. (2005). Statistical methods for health care research (5th ed.). Philadelphia, PA: Lippincott Williams \& Wilkins.

Murcia, S. E. A., \& Lopez, L. (2016). The experience of nurses in care for culturally diverse families: A qualitative meta-synthesis. Revista Latino-Americana de Enfermagem, 24. https://doi.org/10.1590/15188345.1052.2718

Murphy. K. (2011). Editorial: The important of cultural competence. Nursing Made Incredibly Easy, 9(2), 5. 
Olin, J. (2011). Guidelines for Culturally Competent Nursing Care. Retrieved from http://www.rncentral.com/blog/ 2011/guidelines-for-culturally-compe tent-nursing-care/

Shen, Z. (2015). Cultural Competence Models and Cultural Competence Assessment Instruments in Nursing: A Literature Review. Journal of Transcultural Nursing, 18(2), 95-102. https://doi.org/10.1177/10436596145 24790

Sindayigaya, F. (2016). How do nurses feel about their cultural competence? A Literature. Retrieved from https: //www.theseus.fi/bitstream/handle/10 $024 / 125280$

Tavallali, A. G., Kabir, Z. N., \& Jirwe, M. (2014). Ethnic Swedish Parents' experiences of minority ethnic nurses' cultural competence in Swedish paediatric care. Scandinavian Journal of Caring Sciences. https://doi.org/10.1111/ scs. 12051

The National Institutes of Health. (2017). Cultural Respect. Retrieved from https://www.nih.gov/institutes-nih/nih -office-director/office-communication s-public-liaison/clear-communication/ cultural-respect

Waltz, C. F, Strickland, O. L., \& Lenz, E. R. (2017). Measurement in nursing research. New York, NY: Springer Publishing Company.

Wikipedia. (2018). Culture of IndonesiaNo Title. Retrieved from https://en.wiki pedia.org/wiki/Culture_of_Indonesia 